\title{
RESENHA Sopa de Wuhan: pensamiento contemporáneo en tiempos de pandemias
}

Gleisson Roger de Paula Coêlho ${ }^{1}$ Marina Garcia Lara ${ }^{2}$ Universidade Federal de Mato Grosso



AGAMBEN, Giorgio; et al. Sopa de Wuhan: pensamiento contemporáneo en tiempos de pandemias. Madrid: ASPO, 2020. 188 p.

${ }^{1}$ Possui graduação em Ciências Jurídicas pela Universidade do Estado de Mato Grosso (2005), especialização em Direito do Trabalho e Previdenciário na Atualidade pela Pontifícia Universidade Católica de Minas Gerais (2017), especialização em Direito Civil Contemporâneo pela UFMT (2017) e especialização em Direitos Humanos e Questão Social pela Pontifícia Universidade Católica do Paraná (2020). Atualmente é mestrando do PPGAS/UFMT.

2 Possui graduação em Administração pelo Instituto Cuiabá de Ensino e Cultura (ICEC) e é mestranda do PPGAS/UFMT. 
$\mathrm{P}$ ublicado em espanhol, o livro digital Sopa de Wuhan: Pensamiento Contemporáneo en Tiempos de Pandemia reúne reflexões sobre o contexto da pandemia no período de um mês - entre 26 de fevereiro e 28 de março de 2020 - sobre as novas realidades vividas em decorrência do coronavírus, e também com reflexões sobre o futuro pós-pandemia a partir de diálogos de 15 autores: Giorgio Agamben, Slavoj Žižek, Jean Luc Nancy, Franco "Bifo" Berardi, Santiago López Petit, Judith Butler, Alain Badiou, David Harvey, Byung-Chul Han, Raúl Zibechi, María Galindo, Markus Gabriel, Gustavo Yañez González, Patricia Manrique e Paul B. Preciado.

O italiano Giorgio Agamben, único autor com três textos no livro, é quem inicia as discussões em 26 de fevereiro em "La invención de una epidemia". O filósofo italiano afirma que o coronavírus seria apenas uma forma diferente de gripe e evidencia o papel dos meios de comunicação e dos governos na disseminação do clima de pânico e descreve o ciclo vicioso ao assegurar que: "la limitación de la libertad impuesta por los gobiernos es aceptada en nombre de un deseo de seguridad que ha sido inducido por los mismos gobiernos que ahora intervienen para satisfacerla3" (p. 19). Em "Contagio" o autor parece ainda não acreditar na gravidade da pandemia e reitera que o governo cria um ambiente de pânico para adotar medidas excepcionais, criticando a necessidade do isolamento social e o fechamento de escolas e universidades. O francês Jean-Luc Nancy, por sua vez, tece comentários sobre as afirmações de Agamben e reitera que uma gripe "normal" é capaz de matar diversas pessoas e que o caronavírus pode vitimar ainda mais pessoas. De outra maneira o Nancy destaca que o estado de exceção de converteu na realidade, pois há uma espécie de exceção viral que nos "pandemiza".

Slavoi Žižek, filósofo esloveno, cogita a ideia de que outras epidemias de vírus ideológicos foram evidenciadas em decorrência do coronavírus: notícias falsas, teorias de conspiração e explosões de racismo - tudo aquilo que estava latente em nossa sociedade, apenas esperando para emergir. O filósofo esloveno acredita que, ao contrário do que se imagina, a pandemia não sugere o fim do comunismo chinês e assemelha a catástrofe da pandemia a um golpe a la Tarantino: a epidemia do coronavírus é uma espécie de ataque contra o sistema capitalista global, um sinal de que não podemos seguir o caminho sem que uma mudança radical aconteça.

Com escritos em formato de diário, Franco Berardi relata, a partir do dia 21 de fevereiro, quando retornou de Lisboa para Bolonha, sua vivência no período de pandemia, inclusive pintando telas para manter a calma. Para o filósofo italiano: "Lo que provoca pánico es que el virus escapa a nuestro saber: no lo conoce la medicina, no lo conoce el sistema inmunitario4" (p. 37). Em 12 de março, descreve o início da quarentena em toda a Itália, haja vista que o vírus é mais rápido que as medidas de contenção. No fim de seus relatos, em 13 de março, afirma que a questão da igualdade voltou ao centro das atenções.

Por sua vez, Santiago López Petit lembra de como o ato de lavar as mãos se tornou algo mecânico para que a proteção de um seja a proteção de todos, e descreve que situações antes inimagináveis, como escolas fechadas e a impossibilidade locomoção livre tornam-se realidade, ficando expostos ao vírus apenas

3 Tradução livre: "a limitação da liberdade imposta pelos governos é aceita em nome de um desejo de segurança que tem sido induzido pelos mesmos governos que agora interveem para satisfazê-la"

4 Tradução livre: "O que causa pânico é que o vírus está além do nosso conhecimento: não é conhecido pela medicina, não é conhecido pelo sistema imunológico”. 
aqueles que necessitam de dinheiro. Para o filósofo espanhol, por mais que a mobilização pareça ser uma guerra contra a população, o objetivo é salvar vidas, e devido a essa nova realidade, descreve como o sistema neoliberal se vê ameaçado.

Em "El capitalismo tiene sus limites", Judith Butler, ao analisar a situação dos EUA que não tem um sistema de saúde público, inicia suas reflexões destacando que: "El aislamiento obligatorio coincide com un nuevo reconocimiento de nuestra interdependencia global durante el nuevo tempo y espacio que impone la pandemia5" (p. 59). Afinal, para o vírus não existem fronteiras e muito menos a ideia de um território nacional, o que nos leva a pensar sobre igualdade, interdependência global e as obrigações mútuas, mas destaca que a exploração capitalista encontra um jeito de se fortalecer e se reproduzir nas zonas de pandemia. A filósofa estadunidense faz uma crítica ao presidente norte-americano Donald Trump, que tenta se aproveitar da situação para assegurar sua reeleição, na sua tentativa de comprar as vacinas de uma companhia alemã. Embora em um primeiro momento se acredite que o vírus não escolheria classe social, idade e sexo, a desigualdade social e econômica que estamos tratando de um vírus discriminatório.

Alain Badiou destaca que embora a pandemia viral não seja muito diferente de outras vividas pela humanidade - como a gripe aviária, o Ebola, entre outros o que difere dessa vez, mesmo sendo a segunda desse tipo nesse século, "la pandemia actual golpea esta vez a gran escala al llamado mundo occidental6". Para o filósofo franco-marroquino a epidemia atual surgiu, provavelmente, nos mercados da província de Wuhan, na China, onde vários animais vivos são vendidos de forma amontoada, e que, possivelmente, um deles havia sido contaminado. Mesmo após a pandemia, o autor não acredita que haverá uma consequência política para nos países, especialmente no caso francês.

David Harvey faz um estudo sobre os reflexos da pandemia no modelo econômico dominante que, em sua opinião pessoal, já passava por dificuldades, pois o "modelo neoliberal descansa de manera creciente en capital ficticio y em una ingente expansión de la oferta de dinero y creación de deuda7" (p. 81). Para o filósofo inglês, a natureza não está separada da cultura, da economia e da vida cotidiana, e que devido as alterações ambientais causadas pelo capital, os vírus sofrem mutação para permanecerem seguros, e consequentemente podem acabar se tornando uma ameaça a vida humana. $O$ autor acredita que o coronavírus não foi tratado com seriedade desde o início, e que ações foram tomadas apenas em março após o surto na Itália, e, corroborando com o texto de Judith Butler, o autor diz que se trata, sim, de uma pandemia de classe, gênero e raça.

Byung-Chul Han contrapõe o ponto levantado por Žižek e destaca um melhor controle da pandemia por parte dos países asiáticos em relação aos europeus/ocidentais, especialmente através de uma vida cotidiana organizada, vigilância digital e um bom comportamento por parte da população. O filósofo sul-coreano lembra que o fato de estar se vivendo sem inimigos desde a guerra fria e se estar vivendo em "la sociedad del cansancio" (sociedade da fadiga) fez com que se perdesse a vigilância e o paradigma imunológico, lembrando que "La globalización



\footnotetext{
5 Tradução livre: "O isolamento obrigatório coincide com um novo reconhecimento de nossa interdependência global durante o novo tempo e espaço que impõe a pandemia".

${ }^{6}$ Tradução livre: "a atual pandemia está atingindo o mundo ocidental dessa vez em grande escala".

7 Tradução livre: "modelo neoliberal depende cada vez mais do capital fictício e de uma expansão da oferta monetária e criação de dívidas”.

8 Tradução livre: "A globalização suprime todas as barreiras imunológicas para dar via livre ao capital”.
} 
Raúl Zibechi, por sua vez, afirma o caos do sistema-mundo acrescido do declínio da hegemonia estadunidense e da contínua ascensão como potência global da China. A pandemia, que afetou em maior intensidade tanto os Estados Unidos, a União Europeia e os países latino-americanos não atingiu com a mesma intensidade os países asiáticos. O pensador uruguaio afirma "la pandemia es la tumba de la globalización neoliberal, em tanto la del futuro será una globalización más "amable", centrada em China y Asia Pacífico9".

María Galindo relata as diversas faces do coronavírus que de uma enfermidade, se transforma em ordem de confinamento, uma permissão para serem extintas as liberdades, uma forma de se eliminar os espaços sociais, bem como uma arma de destruição e proibição aparentemente legitima. A feminista boliviana destaca que devido as condições dos hospitais que foram construídos em sua maioria no início do século XX, os parentes dos doentes se organizam para que não sejam hospitalizados, devido ao medo, e chama atenção sobre as medidas copiadas de economias, que nada se relacionam com as da Bolívia: não os protegem do contágio e muitas vezes podem privar de sua forma de subsistência.

Markus Gabriel descreve, com exatidão, aquilo que temos vivido desde a publicação de seu texto: trata-se de um vírus cuja magnitude desconhecemos, que não se sabe ao certo quantas pessoas estão infectadas, quantas morrerão e em quanto tempo haverá uma vacina. Um ponto relevante é a ineficácia da ideia de fechamento das fronteiras entre os Estados pois "todos estamos unidos por un cordón invisible, nuestra condición de seres humanos ${ }^{10 "}$ (p. 130). Para o professor e filósofo alemão, o coronavírus revela as fraquezas da ideologia dominante do século XXI, tendo em vista que existe uma crença equivocada de que o progresso científico e tecnológico seria suficiente para incentivar o progresso humano.

Agamben em sua última contribuição fala sobre a reação das pessoas diante da pandemia, de como a sociedade "aceitou" ter suspensa sua condição normal de vida. Destaca que talvez como ponto positivo traga a reflexão sobre se a forma que vivíamos era a correta. Ademais, apresenta uma reflexão sobre a fé e de como as religiões se contradizem sobre a gravidade da pandemia, e que talvez as pessoas que continuam mantendo o mínimo de clareza consigam voltar a viver como antes.

Gustavo Yañez González relata que, apesar de outros eventos fatídicos terem acontecido no último século, nada se compara ao Covid-19. O vírus evidencia duas características comuns aos seres humanos: a animalidade constituinte e a fragilidade imunológica frente ao desconhecido. O chileno sugere uma hospitalidade diante de um hóspede que não desejamos e que a fragilidade é a condição e a causa dos nossos sentimentos de medo, solidão e incredulidade. Ademais, recorda Agamben e concorda que a instalação de restrições de liberdades reforça o sentimento de medo e apatia, já que qualquer um pode portar o vírus.

Patricia Manrique assevera que para compreender o que está acontecendo nesse período de pandemia, é necessário tempo. A autora espanhola destaca a hospitalidade, sobre como tratamos e nos comportamos com os estrangeiros perante a alteridade geral. Uma das primeiras evidencias a ser observada é que se está nas mãos de psicopatas e de um sistema necropolítico, que escolhe quem matar e quem expor. Por fim, destaca que essa Europa autônoma e desumana que se acreditava invulnerável agora se vê fragilizada.

9 Tradução livre: "A pandemia é o túmulo da globalização neoliberal, e no futuro existirá uma globalização mais "amigável", centrada na China e nos países asiáticos do Pacífico".

10 Tradução livre: "todos estamos unidos por um laço invisível, nossa condição de seres humanos". 
O artigo de Paul Preciado, filósofo espanhol, finaliza a coletânea e retoma algumas noções de Foucault para pensar em epidemia tendo em vista que o corpo humano é o objeto central de toda a política (biopolítica) e o poder regula a vida e a morte das populações. Neste sentido, evidencia que estamos diante de formas de controle do corpo e sugere mudanças: "en primer lugar, es imperativo cambiar la relación de nuestros cuerpos con las máquinas de biovigilancia y biocontrol: estos no son simplemente dispositivos de comunicación"11 (p. 185).

Sopa de Wuhan visa descrever, compreender e problematizar o comportamento dos indivíduos em diversos países do mundo em relação a pandemia. No cenário brasileiro, percebemos a falta de confiança da população e os governantes que minimizam a pandemia à uma gripezinha. Sopa de Wuhan é um convite ao conhecimento, ao debate de ideias e à noção do bom senso - que deveria ser comum a todos nesses árduos tempos em que vivemos. Por fim, reiteramos a ideia proposta por Preciado (p. 16o): "cambiar la mirada abre puertas a nuevas soluciones". ${ }^{12}$

Recebido em 14 de setembro de 2020.

Aprovado em 15 de outubro de 2020.

${ }^{11}$ Tradução livre: "Em primeiro lugar, é necessário mudar a relação dos nossos corpos com as máquinas de biovigilância 